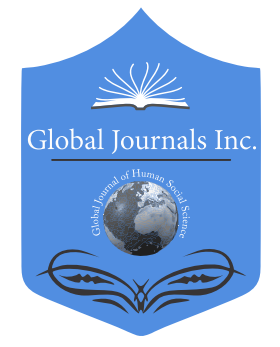

\title{
Lecture Notes on the Application of the Functions of Semantic Categories in Translation
}

By Servais Martial Akpaca

Université d'Abomey-Calavi (UAC)

Abstract- The aim of this paper is to shed light on the contribution of semantic categories to translation. To this end, the paper uses both a theoretical and a descriptive approach. Indeed, the theories relating to the terms category and semantic categories are presented. Then, the functions of semantic categories are described in translated sentences. Finally, the paper has found that the kernels of English sentences together with the transformations that can be derived from every clause or phrase are key aspects of sentence comprehension and stylistic differences. Equally important is the finding that translation becomes easier and more technical when the functions of semantic categories are applied in sentence construction.

Keywords: semantic categories, translation, kernels, parts of speech, transforms.

GJHSS-G Classification: FOR Code: 200323

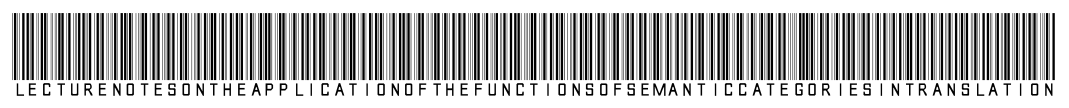

Strictly as per the compliance and regulations of:

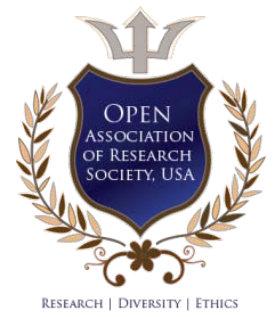

(C) 2020. Servais Martial Akpaca. This is a research/review paper, distributed under the terms of the Creative Commons Attribution-Noncommercial 3.0 Unported License http://creativecommons.org/licenses/by-nc/3.0/), permitting all non-commercial use, distribution, and reproduction in any medium, provided the original work is properly cited. 


\title{
Lecture Notes on the Application of the Functions of Semantic Categories in Translation
}

\author{
Servais Martial Akpaca
}

\begin{abstract}
The aim of this paper is to shed light on the contribution of semantic categories to translation. To this end, the paper uses both a theoretical and a descriptive approach. Indeed, the theories relating to the terms category and semantic categories are presented. Then, the functions of semantic categories are described in translated sentences. Finally, the paper has found that the kernels of English sentences together with the transformations that can be derived from every clause or phrase are key aspects of sentence comprehension and stylistic differences. Equally important is the finding that translation becomes easier and more technical when the functions of semantic categories are applied in sentence construction.
\end{abstract}

Keywords: semantic categories, translation, kernels, parts of speech, transforms.

Résumé Le but du présent article est de faire la lumière sur la contribution des catégories sémantiques à la traduction. Pour atteindre ce but, l'article adopte une double approche théorique et descriptive. En effet, les théories relatives aux termes 'catégorie' et 'catégories sémantiques' sont présentées. Ensuite, les fonctions des catégories sémantiques sont décrites dans des phrases traduites. Enfin, l'article a découvert que les standards des phrases anglaises ainsi que les transformations syntaxiques découlant d'une phrase ou d'un groupe de mots sont des aspects clés qui facilitent la compréhension de la phrase et des différences stylistiques. II est également important de souligner que la traduction devient plus facile et plus technique lorsque les fonctions des catégories sémantiques sont appliquées lors du processus de construction de phrases.

Mots clés: catégories sémantiques, traduction, kernels, différentes parties du discours, transformations syntaxiques.

\section{INTRODUCTION}

T ranslation theorists, including $\mathrm{Nida}$, have noted that translation is the transfer of meaning from one language to another. This transfer concerns not only the message (i.e. the content) but also the form (i.e. the structure). Therefore, both the content and the form of a message are transferred from a source language to a target language.

At this early stage, it is important to note that the word transfer, for example, has been used several times with different functions in the sentences above. In the very first sentence, it is used as a noun, while in the third sentence, it is used as a verb. The use of the terms noun and verb is interesting in this discussion because they remind us of the traditional parts of speech which

Author: Department of English, Université d'Abomey-Calavi (UAC), Republic of Benin. e-mail: akpacasm@yahoo.fr include 'nouns, verbs, adjectives, adverbs, pronouns, prepositions/adpositions, conjunctions, and articles'. In English grammar, these are called 'grammatical categories', while in semantics, they are called 'semantic categories'. Thus, from the perspective of semantics, the noun 'transfer' represents an object, while the verb 'transfer' expresses a process. Before going farther in this discussion, it is worth pointing out that a sort of confusion has prevailed regarding the terminology relating to grammatical categories and/or syntactic categories. In Syntactic Categories; Their Identification and Description in Linguistic Theories, Rauh $(2010$, p. 1) alludes to this confusion by making the following point:

"What is immediately obvious is a variety of terminology, including the terms 'parts of speech', 'word classes', 'form classes', 'lexical categories', 'grammatical categories', and 'syntactic categories'. What often remains unclear is whether these terms refer to different kinds of categories or whether they are more or less synonymous."

The confusion seems to persist given that all these terms are used to refer to sentence constituents which are verbs, nouns, pronouns, adjectives, phrases and so on. Haspelmath (2001: 16539) also admits that there is a sort of opacity surrounding some of these terms.

Besides the term word class, the older term part of speech (Latin pars orationis) is still often used, although it is now quite opaque (originally it referred to sentence constituents)... Another roughly equivalent term, common especially in Chomskyan linguistics is 'syntactic category' (although technically this refers not only to lexical categories such as nouns and verbs, but also to phrasal categories such as noun phrases and verb phrases).

However, Haspelmath and Sasse eventually admitted that syntactic categories and parts of speech are fully equivalent terms. "Sasse, and also Haspelmath, not only considers syntactic categories and parts of speech as 'roughly equivalent', but apparently as 'fully equivalent', for he states: 'The analysis of syntactic categories was familiar to the traditional grammarians under the title parts of speech" (1993, p. 646). Croft has also joined Haspelmath and Sasse by admitting that syntactic categories and parts of speech are equivalent. "The same applies to Croft, who originally described noun, verb, and adjective as 'syntactic categories' (1984, 1990, 1991), but later gives the very same description of the very same categories 
for 'parts of speech' (2000, 2001, 2005). (Rauh, op. cit., p. 4)

The fact that these authors agreed that syntactic categories and parts of speech are equivalent does not yet clarify the point this paper intends to make on the functions of semantic categories in translation. Indeed, the term semantic categories has so far not appeared among the terms evoked in the previous paragraphs of this introduction. In other words, there is a need to clarify the link (if any) between parts of speech, syntactic categories and semantic categories. In this connection, McCawley (1970, p.531) states that "At the abstract level no distinction is drawn between syntactic and semantic categories. I believe that . . . syntactic and semantic representations are objects of the same formal nature."

The next question that comes to mind is: What is important about the application of the functions of semantic categories in translation? On the strength of the theories developed by Rauh, Nida and Banks, this paper will demonstrate how the semantic categories, namely objects, events, abstracts and relations, make translation easier and clearer.

\section{Problem Statement and Methodology}

\section{a) Problem Statement and definition of the term category}

In most translation courses, a heavy emphasis is laid on translation strategies and/or procedures as well as on the history of translation, the problems of equivalence, the various types of translation, etc. However, the functions of semantic categories in translation are given little attention. Indeed, the science of translating can be made easier if students or professional translators are aware of the vital functions semantic categories such as objects, events, abstracts and relations perform in sentence construction.

To discuss the functions of semantic categories, it is necessary to understand what the term category means.

\section{b) Definition of the term category}

In Syntactic Categories; Their Identification and Description in Linguistic Theories, Rauh defines the term category as follows:

Categorizing is a fundamental aspect of how humans process reality. The formation of categories gives structure to the enormous amount of sensory input. Items that share properties are combined to form groups, and it is these groups that define categories. Because of the shared properties of their members, categories enable us to formulate generalizations. In the human perception of reality, the formation of categories thus serves cognitive economy. Insights and statements no longer refer to individual items, but can be generalized to whole groups which are subsumed under categories. (2010, p. 1)
Having defined the term category, the next issue that this paper addresses is the presentation of the research methodology.

\section{c) Methodology}

In a bid to explore the contribution of semantic categories to translation, this paper adopts a two-fold approach, namely a theoretical approach, which sheds light on the definition of the terms 'categories', 'semantic categories' and 'kernels', and a descriptive approach which proceeds to analyse and describe a pattern of sentence construction using the functions of semantic categories. This second approach includes several examples of sentences translated into English using the functions of semantic categories.

Another important aspect of this research is the presentation of its results which will be followed by a discussion of the same.

\section{Results}

a) English sentences are constructed on the basis of roughly half a dozen kernels which may lead to differences in style.

b) The application of the functions of semantic categories makes translation clearer and easier because the functions of nouns, verbs as well as adverbs, adjectives, prepositions and conjunctions in a sentence are known in advance.

c) Non-congruent forms in a sentence lead to grammatical metaphor.

\section{ili. Discussion}

a) Discussion of Result 1: English sentences are constructed on the basis of roughly seven kernels which may lead to differences in style.

Nida has given as examples seven sentences representing the kernel expressions in English. According to him, the basic grammatical structures of the language can be constructed from these types:

1. John ran quickly.

2. John hit Bill.

3. John gave Bill a ball.

4. John is in the house.

5. John is sick.

6. John is a boy.

7. John is my father. (Nida, op. cit., p. 40)

In these sentences, there are subjects, verbs, adverbs, complements, articles, phrases, adjectives and pronouns, i.e. the constituents of a sentence.

In kernel 1, John is the subject of the verb ran. John is a noun that can be represented as a semantic category of object word. In this same kernel, 'quickly' is an adverb. It is also a semantic category representing a qualitative abstract. 
In sentence 4 'John is in the house', 'in the house' is a prepositional phrase. Examples of prepositional phrase include 'with a pen', 'through the glass', 'on the table'.

In kernel 5 'John is sick', sick is grammatically an adjective and semantically a qualitative abstract.

Kernels 6 and 7 are profoundly different because whereas one can say 'my father is John' or 'John is my father', no one can say 'a boy is John'.

Nida is quoted as saying that: "In fact, one of the most important insights coming from "transformational grammar" is the fact that in all languages there are half a dozen to a dozen basic structures out of which all the more elaborate formations are constructed by means of so-called "transformations." (1982, p. 39)

Let us now examine the following examples given by Nida in order to show the relationships between words in a phrase or sentence: In the phrase the God of peace, we are not speaking of a peaceful God, but God who causes or produces peace. (Ibid, p. 36) Nida says that if we proceed to analyze all of these phrases in terms of their simplest and most unambiguous relationships, we come out with the following series:

Biblical Phrases

\begin{tabular}{|l|l|l|}
\hline \multicolumn{1}{|c|}{ The will of God } & \multicolumn{1}{|c|}{ God wills } \\
\hline The foundation/creation of the world & (God) creates the world & \\
\hline The God of peace & God causes/produces peace & \\
\hline$\cdot$ The Holy Spirit of promise & God promised the Holy Spirit & \\
\hline The word of truth & the word is true & \\
\hline baptism of repentance & (people) repent and are baptized & \\
\hline remission of sins & (God) forgives (the people's) sins (Ibid, p. 37) & \\
\hline
\end{tabular}

On page 41, Nida gives another example of words with complex semantic structures. Servant and Lord, for example, in the contexts servant of all and the Lord of the sabbath identify both objects and events, for the kernels underlying these expressions are: "He serves all," or "one (w-ho) serves all," and "He commands/ controls the sabbath." It needs to be underlined that servant is an action-word while all represents an object.

The point Nida is making throughout these examples is that in a given sentence or phrase, a wary translator should try and understand the message of the source language text and should assign functions to semantic categories, namely objects, events, abstracts and relations, in his/her translation.

We have, at one time or another, already made use of the terms object, event, abstract, and relational. It becomes crucial at this point to explain just what we mean by these terms. In the first place, they refer to basic semantic categories, in contrast with the more familiar terms noun, verb, adjective, preposition, etc., which refer to grammatical classes. Second, these four categories include exhaustively all the semantic subcategories of all languages, even though various languages have quite different sets of grammatical classes; in other words, they are universal. This means that the entire universe of experience is divided among these four categories. (Ibid, p.37-38)

According to Nida, Object refers to those semantic classes which designate things or entities which normally participate in events, e.g. house, dog, mall, etc. Event is the semantic class which designates actions, processes, happenings, e.g. run, jump, kill. Abstract refers to the semantic class of expressions which have as their only referents the qualities, quantities, and degrees of objects, events, and other abstracts. For example, red is nothing in and of itself; it is only a quality inherent in certain objects, e.g. red hat, red binding, red face. Relations are the expressions of the meaningful connections between the other kinds of terms. Often they are expressed by particles (in English many are prepositions and conjunctions)

Having established the functions of the various semantic categories, Nida says that they may lead to differences in style. To illustrate this statement, we just have to examine the various transforms of the following sentence: 'Rita sings beautifully.'

\begin{tabular}{|c|c|c|c|c|c|c|c|c|c|c|}
\hline & $\begin{array}{l}\text { Rita sings } \\
\text { beautifully. }\end{array}$ & & $\begin{array}{l}\text { The beauty of } \\
\text { Rita's singing }\end{array}$ & & $\begin{array}{l}\text { Rita's beautiful } \\
\text { singing }\end{array}$ & & $\begin{array}{l}\text { The beautiful } \\
\text { singing of Rita }\end{array}$ & & $\begin{array}{l}\text { Rita's singing is } \\
\text { beautiful. }\end{array}$ & 6. etc. \\
\hline
\end{tabular}

In the sentence 'Rita sings beatifully', Rita is a an object-word; sings represents an event or an action; beautifully is a qualitative abstract. Furthermore, this sentence or clause can be transformed as follows: (2)
The beauty of Rita's singing; (3) Rita's beautiful singing; (4) the beautiful singing of Rita; (5) Rita's singing is beautiful. 
In these phrases and clauses, some of them contain the object word beauty, while others contain the qualitative abstracts beautiful and beautifully.

An important point that needs to be made is that among the five points above, there are only two clauses and three phrases. The two clauses are $\mathrm{N}^{\circ} 1$ \& $\mathrm{N}^{\circ} 5$, and the three phrases are $\mathrm{N}^{\circ} 2, \mathrm{~N}^{\circ} 3$ and $\mathrm{N}^{\circ} 4$. Among the phrases, there are two noun phrases and one adjective phrase.

The various transforms of kernel 1 explain the differences in styles between writers and translators. This example shows the relationship between translation and stylistics. Furthermore, the application of the functions of semantic categories makes translation clearer and easier.

b) Discussion of Result 2: The application of the functions of semantic categories makes translation clearer and easier because the functions of nouns, verbs as well as adverbs, adjectives, prepositions and conjunctions are known in advance.

Below are examples of sentences illustrating the functions of some of the semantic categories in translation.

$1^{\text {st }}$ example: Events are expressed by verbs in English and by nouns in French

\begin{abstract}
Before travelling, the chiefs were feted at the Victoria hotel in Entebbe, Uganda, where they were instructed on how to use the table cutlery and act like "gentlemen". (Gona, 2002, p. 24)
\end{abstract}

Avant le voyage, les chefs furent conviés à une fête à l'hôtel Victoria à Entebbe (Ouganda), où on leur apprit à utiliser les couverts et à se comporter comme des «gentlemen". (Gona, 2004, p. 26)
In this example, the actions, processes or events are expressed by the present participle of the verb to travel and by the verb fete in English, while they are expressed by the nouns voyage and fête in French.

The use of the -ing form is compulsory after the adverb before but other formulations are possible, e.g. before the journey or prior to the trip, etc. These insinuate another aspect of lexical semantics that will be discussed at a later stage. Equally important is the use of the verb to fete which means fêter in French but this verbal form cannot be used in this context. In the French language, you cannot fete someone. You can only invite someone to a feast. That is why the periphrasis conviés à une fête has been used instead.

$2^{\text {nd }}$ example: Events are expressed by verbs in English and by nouns in French

His stay in England officially ended in June, but he did not return to Bukoba until August to the chagrin of his employers. (lbid, p. 25)
Son séjour en Angleterre prit officiellement fin en juin, mais jusqu'en août il n'était pas retourné à Bukoba, à la grande déception de ses employeurs. (Ibid, p. 26)
In this second example, the verb 'ended' (which expresses a happening or an event) is translated into French using the noun ' $f n^{n}$ ', which is a transposition characterised by a change of grammatical category. Here again English is attached to a verbal form to express an event.

3rd example: Events are expressed by verbs in English and by nouns in French What interests us is the flavour it added to the
prospect of founding a pan-African trade union unity
and how Andrew fitted in this process. (Ibid, p. 90)
Ce qui nous intéresse, c'est la saveur qu'elle ajouta à la perspective de la création de l'unité syndicale panafricaine et la manière dont Andrew s'adapta au processus. (lbid, p. 99)

The present participle of the verb to found (which performs the semantic function of process or action) is used to express an event in English, while the noun création is used in the French translation.

$4^{\text {th }}$ example: Events are expressed by verbs in English and by nouns in French

Andrew later championed for unions to be delinked from ruling parties in post-independence Tanganyika and Africa in general. (Ibid, p. 50)

The process of championing for unions to be de-linked from ruling parties is expressed by the noun 'champion' in French.
Andrew a plus tard été le champion de la lutte pour la dissociation des syndicats et des partis au pouvoir à Tanganyika au cours de la période post-indépendance et en Afrique en général. (lbid, p. 55) 
5th example: Exercise relating to three versions of the Bible: two English versions and one French version.

This example is drawn from TAPOT by Nida except the French translation.

Compare Philippians 2: 1-5 in the ASV and the TEV and the TOB (French)

\begin{tabular}{|c|c|c|}
\hline ASV & TEV & TOB (French) \\
\hline $\begin{array}{l}\text { "So if there is any } \\
\text { encouragement in Christ, } \\
\text { any incentive of love, any } \\
\text { participation in the Spirit, } \\
\text { any affection and } \\
\text { sympathy, complete my } \\
\text { joy by being of the same } \\
\text { mind, having the same } \\
\text { love, being in full accord } \\
\text { and of one mind." }\end{array}$ & $\begin{array}{l}\text { "Does your life in Christ make you strong? } \\
\text { Does his love comfort you? Do you have } \\
\text { fellowship with the Spirit? Do you feel } \\
\text { kindness and compassion for one another? } \\
\text { I urge you, then, make me completely } \\
\text { happy by having the same thoughts, } \\
\text { sharing the same love, and being one in } \\
\text { soul and mind." (Nida, op. cit., p. 39) }\end{array}$ & $\begin{array}{l}\text { S'il y a donc un appel en Christ, un } \\
\text { encouragement dans l'amour, une } \\
\text { communion dans l'esprit, un élan } \\
\text { d'affection et de compassion, alors } \\
\text { compétez ma joie en vivant en plein } \\
\text { accord. Ayez un même amour, un même } \\
\text { cœur; recherchez l'unité. }\end{array}$ \\
\hline
\end{tabular}

Compare the following corresponding phrases:

\begin{tabular}{|l|l|l|}
\hline \multicolumn{1}{|c|}{ RSV } & \multicolumn{1}{|c|}{ TEV } & \multicolumn{1}{c|}{ TOB } \\
1a. encouragement & 1b. make you strong & 1\&2: encouragement dans l'amour \\
2a. incentive of love & 2b. his love comfort vou & 3. une communion dans l'esprit \\
3a. participation in the Spirit & 3b. you have fellowship with the Spirit & 4\&5. un élan d'affection et de compassion \\
4a. affection & 4b. you feel kindness & \\
5a. sympathy & 5b. compassion for one another & \\
\hline
\end{tabular}

Answer the followving questions:

1. What makes the verb expressions in $1 b, 2 b, 4 b$, and $5 \mathrm{~b}$ clearer than corresponding noun expressions in $1 \mathrm{a}, 2 \mathrm{a}, 4 \mathrm{a}$, and $5 \mathrm{a}$ ?

2. What is the value of the use of pronouns you, his, and one another in the phrases of the TEV series?

3. What is the justification, if any, for using these verbs and pronouns?

\section{KERNEL SENTENCES}

Now if we examine carefully what we have done in order to state the relationships between words in ways that are the clearest and least ambiguous, we soon discover that we have simply recast the expressions so that events are expressed as verbs, objects as nouns, abstracts (quantities and qualities) as adjectives or adverbs. The only other terms are relationals, i.e., the prepositions and conjunctions. (Nida, 1982, p. 39)

However, instances of sentences in which nouns are used to express processes and events are abundant in English. These are called non-congruent forms.

c) Discussion of Result No3: Non-congruent forms in a sentence lead to grammatical metaphor.

Writers using nouns to express events may ultimately wish to achieve a particular lexical effect. In an article titled The evolution of grammatical metaphor in scientific writing, Banks informs us that even in English nouns are used to express actions and this leads to the notion of grammatical metaphor.

"The term grammatical metaphor has come to be used as a convenient label for the use of non-congruent lexico- grammatical forms... the form of grammatical metaphor which has received the most attention is the nominalisation of processes, and indeed in some treatments it is the only form discussed (Eggins 1994, Bloor \& Bloor 1995). Processes are congruently encoded as verbs, when they are encoded as something else, such as nouns, we have a noncongruent form, and this constitutes a grammatical metaphor". Banks (2003, p. 127-129)

This quotation not only gives credence to Nida's semantic categories but it also points out that there are non-congruent uses of nouns which express processes instead of representing objects. Banks has further mentioned the names of Ravelli and Halliday who have come up with several types of nominalisation of processes. Indeed, Ravelli has identified material, mental, relational, verbal and behavioural processes; while Halliday has divided processes into events, aspect or phase and modality.

Furthermore, Banks has given examples of sentences in which the word trawl is used successively to name some equipment and to express an action. It is of course the second use of the word which constitutes grammatical metaphor: "...no fish were assumed captured while the trawl was retrieved" (Krieger \& Sigler 1996:283) and "The time between dives and trawls was $<4 \mathrm{~h}$ for 13 of the 16 comparisons." (Krieger \& Sigler 1996: 283) In these examples, the word designates an object but in the following examples, it expresses an action: "Trawl periods ranged from 10 to $18 \mathrm{~min}$, depending on trawl speed and trawl distance needed to intersect the submersible transects." (Krieger \& Sigler 1996: 289) 
In the next section, examples are given to shed light on the concepts of mental, material and existential processes.

\section{Text}

"In the midst of their squalor, black workers were faced with huge increases in the cost of food, rent and transport. Meat prices skyrocketed; increases in the African's staple food - bread and mealie meal were prohibitive. Added to this was the starvation experienced in the reserves, as poor harvest resulting from the drought, the mass unemployment following the deportation of tens of thousands of 'superfluous' Africans from the towns to the Bantustans, and the overall desperation of the African workers" (Gona, op. cit., p. 121)

In the text above, several processes are expressed through the nouns desperation, starvation, increases, harvest, etc. While some of them refer to abstract realities, others represent tangible or visible phenomena.

Halliday's processes, namely events, aspect and modality are prevalent in grammatical constructions. Halliday defines process as follows:

In the quotation above, Halliday's process involves the notion of aspect (i.e. progressive aspect, habitual aspect, etc.) The examples below are given to clarify the notions of aspect and modality.

\begin{tabular}{|l|l|l|}
\hline \multicolumn{1}{|c|}{ Sentence } & \multicolumn{1}{c|}{ Aspect } & \multicolumn{1}{c|}{ Modality } \\
\hline ia mis going to the airport. & Progressive & \\
\hline John spends Sundays on the beach. & Habitual & \\
\hline Ghaham used to go to a military academy. & Habitual past action & \\
\hline Mary has been coming here to see her friends. & Iterative & \\
\hline Paul has eaten bread. & Perfect & Has - modal (auxiliary verb) \\
\hline $\begin{array}{l}\text { Ernest had prepared his lesson before the inspector } \\
\text { came. }\end{array}$ & Plu-perfect & $\begin{array}{l}\text { Had - modal expresses anteriority in the } \\
\text { past }\end{array}$ \\
\hline $\begin{array}{l}\text { Andrew, will you lend me the pen you are writing } \\
\text { with? I just want to write a sentence. }\end{array}$ & & $\begin{array}{l}\text { Will is a modal of volition and not an } \\
\text { auxiliary of the future tense. }\end{array}$ \\
\hline I can drive a car. & & Can expresses capacity. \\
\hline You can go. & & \begin{tabular}{l} 
Can suggests permission. \\
\hline $\begin{array}{l}\text { If you buy the Ittery ticket, you can win up to USD } \\
500 .\end{array}$
\end{tabular} \\
\hline
\end{tabular}

\section{Conclusion}

The function of a word in a sentence depends on the context. In other words, a word can be used as a verb or a noun depending on the context. Furthermore, parts of speech are also called grammatical categories or semantic categories.

English sentences are constructed in accordance with half a dozen kernels. Every kernel can be transformed in a number of ways. By so doing, an adjective may become an adverb in another transform; a noun may become an adjective; a verb may become a present participle in another transform, etc.

The assignment of functions to semantic categories in a sentence makes translation clearer and more technical. In this perspective, verbs express
Processes of all types unfold through time; but the way the process unfolds may vary from one process type to another. In particular, processes of the 'material' type tend to differ from all the other types (with the partial exception of 'behavioural' processes, as we shall see below), and this is seen in how present time is reported. The unmarked tense selection is the present-in-present (e.g. is doing) rather than the simple present. (Halliday \& Matthiessen, 2014, p. 225)
Starvation: existential process

Desperation: mental process

Unemployment, deportation: material (human process)

Increases, harvest: material (non-human) process processes and actions; nouns represent objects; adjectives and adverbs represent qualities, abstract features and quantities; and prepositions and conjunctions are relationals.

There is grammatical metaphor when nouns are used to express actions and processes. These nouns are non-congruent forms.

This paper is just an attempt to give translators a tip in the practice of their profession. It may have limitations regarding the lack of reference to the latest publications on the issue of semantic categories and their application to translation. 


\section{BiBLIOGRAPHY}

Biblical references:

1. American Standard Version. 1901.

2. La Bible (2004). TOB, Société biblique française et Editions du Cerf, Paris Revised Version, The. 1881.

3. Banks, D. (2003). "The evolution of grammatical metaphor in scientific writing." In Grammatical Metaphor: Views from systemic functional linguistics, 127-147

4. Croft, W. (1984). 'Semantic and Pragmatic Correlates to Syntactic Categories', in D. Testen, V. Mishra, and J. Drogo (eds.), Papers from the Parasession on Lexical Semantics, Twentieth Regional Meeting of the Chicago Linguistic Society. Chicago: University of Chicago Linguistics Department, 53-71.

5. - (1986). Categories and Relations in Syntax: The Clause-level Organization of Information. PhD dissertation, Stanford University.

6. — (1990). 'A Conceptual Framework for Grammatical Categories (or: A Taxonomy of Propositional Acts)', Journal of Semantics 7: 245-79.

7. _ (1990 [2003]). Typology and Universals. Second edition. Cambridge: Cambridge University Press.

8. _ (1991). Syntactic Categories and Grammatical Relations: The Cognitive Organization of Information. Chicago: University of Chicago Press.

9. _ (1995). 'Autonomy and Functional Linguistics'. Language 71: 490-532.

10. - (2000). 'Parts of Speech as Language Universals and as Language- Particular Categories', in P. M. Vogel, and B. Comrie (eds.), Approaches to the Typology of Word Classes. Berlin: Mouton de Gruyter, 65-102.

11. - (2001). Radical Construction Grammar. Syntactic Theory in Typological Perspective. Oxford: Oxford University Press.

12. (2005). 'Word Classes, Parts of Speech, and Syntactic Argumentation', Linguistic Typology 9: 441-41.

13. Gona, G. (2002). The Life and Times of an African Trade Unionist, Printpak, Nairobi.

14. Gona, G. (2004). La vie et l'époque d'un syndicaliste africain, Traduit de l'anglais par Servais Akpaca, Printpak, Nairobi.

15. Halliday, MAK \& Matthiessen C. (2014). Halliday's Introduction to Functional Grammar, Fourth Edition, Routledge, Oxon.

16. Haspelmath, M. (2001). "Word Classes and Parts of Speech", in International Encyclopedia of the Social and Behavioral Sciences. P. B. Baltes, and N. J. Smelser (eds), Amsterdam: Pergamon, 16538-45.
17. Jackendoff, R.S. (1972). Semantic Interpretation in Generative Grammar. Cambridge, MA: The MIT Press.

18. (1973). 'The Base Rules for Prepositional Phrases', in S. Anderson, and P. Kiparski (eds.), A Festschrift for Morris Halle. New York: Holt, Rinehart and Winston, 345-56.

19. - (1977a). 'Constraints on Phrase Structure Rules', in P. Culicover et al. (eds.), Formal Syntax. New York: Academic Press, 249-83.

20. — (1977b). X'-Syntax: A Study of Phrase Structure.Cambridge, MA: The MIT Press.

21. (1983). Semantics and Cognition. Cambridge, MA: The MIT Press.

22. (1987). Consciousness and the Computational Mind. Cambridge, MA: The MIT Press.

23. - (1990). Semantic Structures. Cambridge, MA: The MIT Press.

24. (1993). 'X-bar Semantics', in J. Pustejovsky (ed.), Semantics and the Lexicon. Dordrecht: Kluwer, 15-26.

25. (1997). The Architecture of the Language Faculty. Cambridge, MA: The MIT Press.

26. Krieger \& Sigler. (1996). Grammatical Metaphor: Views from Systemic Functional Linguistics, eds. A. M. Simon-Vandenbergen, Miriam Taverniers, Louise Ravelli.

27. McCawley, J., "The Role of Semantics in a Grammar", in Universals in Linguistics ... Foundations of Language 5. (1969), pp. 520-533.

28. Nida, E. (1982). The Theory and Practice of Translation, J. BRILL, LEIDEN.

29. Rauh, G. (2010). Syntactic Categories; Their Identification and Description in Linguistic Theories. Oxford University Press Inc., New York. 